\title{
Polyethylene Glycol: A Cheap and Efficient Medium for the Thiocyanation of Alkyl Halides
}

\author{
Ali Reza Kiasat" and Mehdi Fallah-Mehrjardi \\ Chemistry Department, Faculty of Sciences, Shahid Chamran University, Ahvaz 61357-4-3169, Iran. "E-mail: akiasat@sctaacir \\ Received July 30,2008
}

\begin{abstract}
$\Lambda$ novel, efficient and eco-friendly method is described for the synthesis of alkyl thiocyanates from alkyl halides. The reaction was carried out by treatment of various alkyl halides with ammonium thiocyanate in polyethylene glycol as reaction media. This procedure afforded the corresponding alkyl thiocyanates in high yields without formation of isothiocyanates as by-products.
\end{abstract}

Key Words : Alkyl halide, Alkyl thiocyanate, Polyethylene glycol, Ammonium thiocyanate

\section{Introduction}

Regulatory pressure is increasingly focusing on the use, manufacture, and disposal of organic solvents, and thus the development of nonhazardous alternatives (one of several goals of green chemistry and engineering) is vitally important for the continued and sustainable development of the chemical enterprise.' In reducing the amount of waste, the energy usage, and the use of volatile, toxic, and flammable solvents, several approaches are available, including avoiding the use of organic solvents for the reaction media. ${ }^{2}$

Altemative solvents include supercritical fluids, ${ }^{3}$ ionic liquids, ${ }^{4}$ solvent-free conditions, ${ }^{5}$ polyethylene glycol, ${ }^{6}$ water ${ }^{7}$ and the use of fluorous solvents. ${ }^{8}$ Polyethylene glycol (PEG) is a hydrophilic polymer, easily soluble in water and many organic solvents including: toluene, dichloromethane, alcohol, and acetone, but it is not soluble in aliphatic hydrocarbons such as hexane, cyclohexane, and diethyl ether.'

Low molecular weight liquid PEGs can be regarded as protic solvents with aprotic sites of binding constituted by some monomeric units $\left(\mathrm{CH}_{2}-\mathrm{CH}_{2} \mathrm{O}\right)$. A few inorganic salts and many organic substrates are soluble in low molecular weight liquid PEGs, and thus, they have been proposed as solvents for organic reactions. PEGs have been termed "host" solvents due to their ability to form complexes with metal cations."

Alkyl thiocyanates are important synthetic precursors for the preparation of sulfur-containing organic compounds. For example, (i) the thiocyanato group occurs as an important functionality in certain anticancer natural products, ${ }^{10}$ (ii) $\alpha$ thiocyanato carbonyl compounds are intermediates for a preferred synthetic route to several types of thiazoles., "(iii) this functional group can be used as a masked mercapto group. Also, alkyl thiocyanates have found a wide variety of applications as insecticides, ${ }^{12}$ bincidal, ${ }^{15}$ antiasthmatic. ${ }^{14}$ vulcanization accelerators, ${ }^{15}$ and starting materials for the preparation of heterocycles. ${ }^{16}$ They are generally prepared via nucleophilic displacement of leaving groups by thiocyanate jon on a carbon atom. $\alpha$-Thiocyanato carbonyl compounds are prepared from $\alpha$-halocarbonyl compounds ${ }^{17}$ or $\alpha$-tosyloxycarbonyls. ${ }^{18}$ Also, $\beta$-hydroxy thiocyanates are prepared via nucleophilic epoxide ring opening using the thiocyanate anion. ${ }^{19}$

In continuation of our work on the new methods for the preparation of alkyl thiocyanates,,$^{20}$ we have described a mild and efficient method for thiocyanation of alkyl halides using ammonium thiocyanate in PEG as reaction medium, which afforded the corresponding alkyl thiocyanates in high yields.

\section{Results and Discussion}

Polyethylene glycol (PEG-400) has been applied here as an efficient reaction medium for the preparation of alkyl thiocyanates. It is a biologically acceptable inexpensive polymer and eco-friendly. Its applications as a reaction medium in organic syntheses have not yet been fully explored. In the present conversion, the role of PEG is possibly to form complexes with cation, much like crown ethers, and these complexes cause the anion to be activated. ${ }^{21}$

In a typical experiment, benzyl bromide $(1 \mathrm{mmol})$ and ammonium thiocyanate $(2 \mathrm{mmol})$ were stirred at room temperature in PEG. In this case, the reaction was not completed after $5 \mathrm{~h}$, but by increasing the temperature to 60 ${ }^{\circ} \mathrm{C}$, the reaction was completed within $1 \mathrm{~h}$ and produced benzyl thiocyanate in quantitative yield (Table 1 , entry 1 ). In spite of this point that prolonged heating over $50^{\circ} \mathrm{C}$ can cause an intramolecular rearrangement to isothiocyanate isomers, ${ }^{22}$ no evidence for the formation of isothiocyanate as by-product of the reaction was observed and the product was obtained in pure form without further purification. ${ }^{13} \mathrm{C}$ resonance of the $-\mathrm{SCN}$ at $\sim 111$ and $-\mathrm{NCS}$ groups at $\sim 145$ $\mathrm{ppm}$, are very characteristic for thiocyanate and isothiocyanate functionalities..$^{23}$

In order to show the general applicability of the method, we extended it to a variety of alkyl halides and in all cases

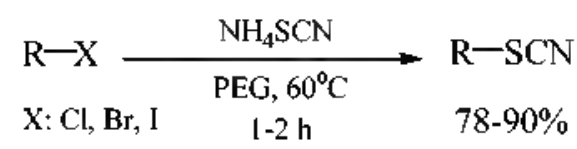

Scheme 1 
Table 1. Reaction of different alkyl halides with $\mathrm{NH}_{\downarrow} \mathrm{SCN}$ using $P E G$ as reaction medium

(s)

"Products were identified by comparison of their physical and spectral data with those of authentic samples. 'Tsolated yields. "Afler l h, l mmol $\mathrm{NH}_{4} \mathrm{SCN}$ was added.

very clean reactions were observed (Table 1). The structures of all the products were settled from their analytical and spectral (IR, ${ }^{13} \mathrm{C}$ NMR) data and by direct comparison with authentic samples.

This procedure can be used for preparation of $\alpha$-thiocyanato carbonyl compounds (Table 1 , entry 11, 12). As expected the typical steric effect on the rate of $S_{k} 2$ reactions was observed. The primary alkyl halides could be efficiently converted to the corresponding alkyl thiocyanates, whereas secondary alkyl halides such as bromo cyclohexane did not convert after 5 h (Table 1, entry 14).

In conclusion, we reported a novel and efficient method for the synthesis of alkyl thiocyanates from their alkyl halides in high isolated yields. More importantly there is no formation of any by-products in this process, and the products can be obtained in pure form without further purification, and we feel that it may be a suitable addition to methodologies already present in the literature.

\section{Experimental Section}

All ${ }^{1} \mathrm{H}$ and ${ }^{13} \mathrm{C}$ NMR data were recorded on a Bruker Advanced DPX $400 \mathrm{MHz}$ instrument spectrometer using TMS as the intemal standard in $\mathrm{CDCl}_{3}$. IR spectra were recorded on a BOMEM MB-Series 1998 FT-IR spectrophotometer. All materials were purchased from Merck Company in high purity. Products were characterized by comparison of their physical and spectroscopic data with those of known samples. The purity determination of the products and reaction monitoring were accomplished by TLC on silica gel polygram SILG/UV 254 plates.

General procedure for the preparation of alkyl thiocyanates from alkyl halides. To a suspension of alkyl halide $(1 \mathrm{mmol})$ in PEG-400 (2 g), NH $\mathrm{SCN}_{4}(2 \mathrm{mmol})$ was added and the mixture was stirred at $60^{\circ} \mathrm{C}$ for the lengths of time shown in Table 1. In some cases (Table 1, entries 6, 7, $11 \& 12$ ), for facile thiocyanation, after $1 \mathrm{~h}$, one more mmol of $\mathrm{NH}_{4} \mathrm{SCN}$ was added to the reaction mixture. The progress of reaction was monitored by TLC using $\mathrm{CCl}_{4}$ as eluent. On completion of reaction, the reaction mixture was poured into water $(10 \mathrm{~mL})$ and extracted with EtOAc $(3 \times 10 \mathrm{~mL})$. The combined organic layers were dried over anhydrous $\mathrm{Na}_{2} \mathrm{SO}_{4}$, filtered and concentrated. The desired alkyl thiocyanates were obtained in high isolated yields.

Representative examples of spectra data of alkyl thiocyanates.

Benzyl thiocyanate 1, 2: IR: 2153 (SCN). ${ }^{1} \mathrm{H}-\mathrm{NMR}(400$ $\left.\mathrm{MHz}_{3} \mathrm{CDCl}_{3}\right): \delta=4.2(\mathrm{~s}, 2 \mathrm{H}), 7.2-7.5(\mathrm{~m}, 5 \mathrm{H}) .{ }^{13} \mathrm{C}-\mathrm{NMR}$ $\left(100 \mathrm{MHz}, \mathrm{CDCl}_{3}\right): \delta=38.5\left(\mathrm{CH}_{2}\right), 112.6(\mathrm{SCN}), 129.3$ $(2 \times \mathrm{CH}), 129.4(2 \times \mathrm{CH}), 129.6(\mathrm{CH}), 134.7(\mathrm{C})$.

2-Phenylethyl thiocyanate 8: IR: 2154 (SCN). ${ }^{1} \mathrm{H}-\mathrm{NMR}$ $\left(400 \mathrm{MHz}, \mathrm{CDCl}_{3}\right): \delta=3.1(\mathrm{t}, 2 \mathrm{H}), 3.2(\mathrm{t}, 2 \mathrm{H}), 7 . \mathrm{I}-7.3(\mathrm{~m}$, $5 \mathrm{H}) .{ }^{13} \mathrm{C}-\mathrm{NMR}\left(100 \mathrm{MHz}, \mathrm{CDCl}_{3}\right): \delta=34.9\left(\mathrm{CH}_{2}\right), 35.8$ $\left(\mathrm{CH}_{2}\right), 112.4(\mathrm{SCN}), 126.7(\mathrm{CH}), 128.2(2 \times \mathrm{CH}), 129.4$ $(2 \times \mathrm{CH}), 138 . \mathrm{I}(\mathrm{C})$.

3-Phenylpropyl thiocyanate 9: IR: 2155 (SCN). ${ }^{1} \mathrm{H}-$ NMR $\left(400 \mathrm{MHz}, \mathrm{CDCl}_{3}\right): \delta=1.9(\mathrm{~m}, 2 \mathrm{H}), 2.6-2.8(\mathrm{~m}, 4 \mathrm{H})$, $7.1-7.3(\mathrm{~m}, 5 \mathrm{H}) .{ }^{13} \mathrm{C}-\mathrm{NMR}\left(100 \mathrm{MHz}, \mathrm{CDCl}_{3}\right): \delta=30.9$ $\left(\mathrm{CH}_{2}\right), 32.8\left(\mathrm{CH}_{2}\right), 33.7\left(\mathrm{CH}_{2}\right), 112.6(\mathrm{SCN}), 126.2(\mathrm{CH})$, $128.3(2 \times \mathrm{CH}), 128.6(2 \times \mathrm{CH}), 139.9(\mathrm{C})$.

1-Naphthylmethyl thiocyanate 10: IR: 2152 (SCN). ${ }^{1} \mathrm{H}-$ NMR $\left(400 \mathrm{MHz}, \mathrm{CDCl}_{3}\right): \delta=4.3(\mathrm{~s}, 2 \mathrm{H}), 7.5-8.1(\mathrm{~m}, 7 \mathrm{H})$. ${ }^{13} \mathrm{C}-\mathrm{NMR}\left(100 \mathrm{MHz}, \mathrm{CDCl}_{3}\right): \delta=36.2\left(\mathrm{CH}_{2}\right), 111.4(\mathrm{SCN})$, $124.3(\mathrm{CH}), 125.8(\mathrm{CH}), 125.9(\mathrm{CH}), 126.1(\mathrm{CH}), 126.4(\mathrm{CH})$, $126.7(\mathrm{CH}), 129.6(\mathrm{CH}), 130.4(\mathrm{C}), 131.8(\mathrm{C}), 135.2(\mathrm{C})$.

Octyl thiocyanate 13: IR: $2155(\mathrm{SCN}) \cdot{ }^{1} \mathrm{H}-\mathrm{NMR}(400$ 
$\left.\mathrm{MHz}, \mathrm{CDCl}_{3}\right): \delta=0.9(\mathrm{t}, 3 \mathrm{H}), 1.3-1.6(\mathrm{~m}, 12 \mathrm{H}), 2.9(\mathrm{t}, 2 \mathrm{H})$. ${ }^{13} \mathrm{C}-\mathrm{NMR}\left(100 \mathrm{MHz}, \mathrm{CDCl}_{3}\right): \delta=16.0\left(\mathrm{CH}_{3}\right), 24.5\left(\mathrm{CH}_{2}\right)$, $30.8\left(\mathrm{CH}_{2}\right), 31.1\left(\mathrm{CH}_{2}\right), 31.7\left(\mathrm{CH}_{2}\right), 31.9\left(\mathrm{CH}_{2}\right), 33.7\left(\mathrm{CH}_{2}\right)$, $33.8\left(\mathrm{CH}_{2}\right), 114.2(\mathrm{SCN})$.

Acknowledgments. The authors are thankful to Shahid Chamran University Research Council for the financial support of this work.

\section{References}

1. Chen, J.; Spear, S. K.; Huddleston, J. G.; Rogers, R. D. Greent Chem. 2005, 7,64.

2. Doble, M.; Kruthiventi, A. K. Green Chemistry \& Engineering; Academic Press is an imprint of Elsevier: $2006 ; p 93$.

3. Prajapati, D., Gohain, M. Tetrahedron 2004, $60(4), 815$.

4. Chang, S. U.; Cho, J. H.; Lee, J. C. Bull. Korean Chent. Soc. 2008. 29,27 .

5. Tanaka, K. Solvent-free Organic Synthesis; Wiley-VCH: Weinheim, 2003.

6. Chandrasekhar, S.; Narsihmulu, Ch.; Chandrashekar, G.; Shyamsunder, T. Tetrahedron Lett. 2004, 45, 2421 .

7. Basaif, S. A.; Sobahi, T. R.; Khalil, A. K.; Hassan, M. A. Bull. Korean Chem. Soc. 2005, 26, 1677.

8. Xu. B. L.; Chen, J. P.; Qiao. R. Z.; Fu. D. C. Chin. Chem. Leff. $2008,19(5) .537$.

9. Santaniello, E; Manzocchi, A.; Sozzani, P. Tetrahedron Lett, $1979,47,4581$

10. Mehta, R. G.; Liu, J.; Constantinou, A.; Thomas, C. F.; Hawthome,
M.; You, M.; Gerhaeuser, C.; Pezzuto, J. M.; Moon, R. C.; Moriarty, R. M. Cancinogenesis 1995, 16, 399.

11. Metzer, J. B. In Comprehensive Heterocychic Chemisfry; Katritzky, A., Ed.; Pergamon: Oxford, 1984; Vol. 6, p 235.

12. Buchel, K. H. Chemie der Pflanzen Schitz-Lind Schadlingsbe Kampfungsmittle; Springer: Berlin Heidelberg, New York, 1970; p 457.

13. Gerson, C.; Sabater, J.; Scuri, M.; Torbati, A.; Coffey, R.; Abraham, J. W.; Lauredo, I.; Forteza, R.; Wanner, A.; Salathe, M.; Abraham, W. M.; Conner, G. E. An. J. Respir. Cell Mol. Biol. 2000, 22, 665 .

14. Akio, M.; Masaaki, K. U. S. Patent 5,155,108; Chem. Abstr. 1991, If, $102028 \mathrm{e}$.

15. Gorl, U.; Wolff, S. DE 4.100,217, 1992; Chem. Abstr. 1992, 117, $152581 \mathrm{n}$.

16. (a) Balanero, B.; Braba, F.; Martina, A. J. Org. Chem, 2002, 67, 2369. (b) Vikharev, Y; Shklyaev, Y; Anikina, L.; Kolla V; Tolstikova, A. Pharm, Chem. J. 2005, 39, 405 .

17. Dittmer, D. C. Comprehensive Heteroochc Chemistry; Katritzky, A., Ed.; Pergamon: Oxford, 1984; Vol. 7, p 178

18. Prakash. O.; Saini, N. Synth. Conmun 1993, 23, 1455.

19. Brimeyer, M. O.; Mehrota, A.; Quici, S.; Nigam, A.; Regen, S. L. J. Org. Chem, 1980, 45, 4254 .

20. (a) Kiasal, A. R; Mehrjardi, M. F. Catal. Commmi. 2008, 9, 1497. (b) Kiasal, A. R.; Zayadi, M.; Mehrjardi, M. F. Chin. Chem. Lett. 2008, 19,665 .

21. Das, B.; Reddy, V. S.; Krishnaiah, M. Tetrahedron Leff. 2006, 47, 8471 .

22. Bacon, R. G R, Guy, R, G. J. Chem, Soc. 1961, 2447.

23. Iranpoor, N.; Firouzabadi, H.; Nowrouzi, N. Tetrahedron 2006, 62,5498 . 